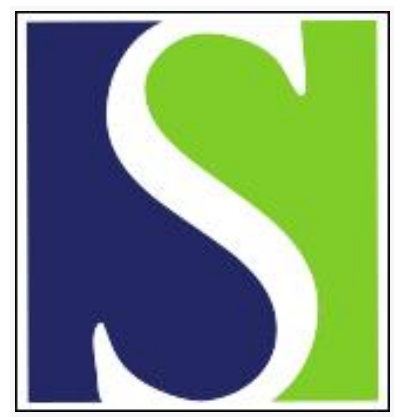

Scand J Work Environ Health 2019;45(6):546-559

https://doi.org/10.5271/sjweh.3833

Published online: 28 May 2019, Issue date: 01 Nov 2019

The effectiveness of workplace health promotion interventions on physical and mental health outcomes - a systematic review of reviews

by Proper KI, van Oostrom SH

This review found evidence of workplace health promotion to prevent weight-related outcomes, depression and musculoskeletal disorders. However, there is an absence of reviews concerning the effectiveness of workplace interventions on the onset of lung diseases, type 2 diabetes, and cardiovascular diseases. It is currently not possible to formulate evidence-based recommendations about which components and in what dose or frequency should be applied.

Affiliation: National Institute for Public Health and the Environment, Center for Nutrition, Prevention and Health Services, Antonie van Leeuwenhoeklaan 9, 3721 MA, Bilthoven, The Netherlands. karin.proper@rivm.nl

Refers to the following texts of the Journal: 2009;35(1):7-18 2010;36(3):202-215 2014;40(3):230-234 2014;40(6):543-556

The following articles refer to this text: 2020;46(5):457-460; 2021;47(8):561-564; 0;0 Special issue:0

Key terms: cardiovascular disease; CVD; diabetes; lifestyle intervention; mental health; meta-review; musculoskeletal disorder; physical health; systematic review; workplace health promotion; workplace health promotion intervention; workplace intervention; worksite health promotion

This article in PubMed: www.ncbi.nlm.nih.gov/pubmed/31134284 


\title{
The effectiveness of workplace health promotion interventions on physical and mental health outcomes - a systematic review of reviews
}

\author{
by Karin Ingeborg Proper, PhD, ${ }^{1}$ Sandra Helena van Oostrom, PhD ${ }^{1}$
}

\begin{abstract}
Proper KI, van Oostrom SH. The effectiveness of workplace health promotion interventions on physical and mental health outcomes - a systematic review of reviews. Scand J Work Environ Health. 2019;45(6):546-559. doi:10.5271/sjweh.3833
\end{abstract}

Objective This systematic review aimed to provide an overview of the effectiveness of health promotion interventions at the workplace on physical and mental health outcomes related to chronic diseases.

Methods A search for reviews published between 2009 and 2018 was performed in electronic databases. References of the included reviews were checked for additional reviews. Workplace health promotion interventions were included if they studied metabolic risk factors as important predictors of type 2 diabetes mellitus (T2DM) and cardiovascular diseases (CVD) or if they studied mental or musculoskeletal health outcomes. Review quality was assessed using the AMSTAR checklist.

Results Of the 23 reviews included, 9 were of high quality. For weight-related outcomes, there was strong evidence for favorable effects of workplace interventions, especially for interventions targeting physical activity and/or diet. For the remaining metabolic risk factors, there was no evidence for a positive effect of workplace health promotion interventions due to the absence of high quality reviews and mixed conclusions between the reviews. There was also strong evidence for a positive, small effect on the prevention of mental health disorders of workplace psychological interventions, especially those that use e- health and cognitive behavioral therapy techniques. Furthermore, strong evidence was found for the prevention of musculoskeletal disorders through workplace interventions, especially resistance exercise training.

Conclusions This review found evidence for the effectiveness of workplace interventions on the prevention of weight-related outcomes as well as mental health and musculoskeletal disorders. Future research is however needed on the factors that contribute to the successful implementation of an intervention.

Key terms cardiovascular disease; CVD; diabetes; lifestyle intervention; meta-review; musculoskeletal disorder; physical health; workplace intervention; worksite health promotion.

With an increase in life expectancy, the number of people with a chronic disease is growing in many developed countries. In the past years, the World Health Organization (WHO) has published several reports highlighting the high incidence of chronic diseases, such as diabetes, cardiovascular disease, chronic respiratory disease, and cancer. These chronic diseases account for approximately half of the global burden of disease $(1,2)$, impact individuals in terms of reduced quality of life, and affect employers who have to deal with negative employment outcomes, such as absence from work.

Mental health disorders together with musculoskeletal disorders are the leading causes of sickness absence and work disability in most developed countries (3-6) The high prevalence of chronic diseases implies a public health challenge associated with higher health care costs and decreased workplace productivity $(7,8)$. Considering the aging population in many western countries, there is a need to prolong active labor force participation. Prevention of chronic diseases and exit from the workforce is therefore essential.

The workplace offers an ideal setting to support the promotion of health of a large proportion of the working population. Offering workplace health interventions is recognized as a feasible and potentially effective strategy for chronic disease prevention and control $(1,2)$.

1 National Institute for Public Health and the Environment, Center for Nutrition, Prevention and Health Services, Bilthoven, The Netherlands.

Correspondence to: Karin Proper, National Institute for Public Health and the Environment, Center for Nutrition, Prevention and Health Services, Antonie van Leeuwenhoeklaan 9, 3721 MA, Bilthoven, The Netherlands. [E-mail: karin.proper@rivm.nl] 
Workplaces offer the opportunity to promote health on an individual level, eg, by means of behavioral change approaches, but can also target environmental changes to promote health behaviors, such as altering the availability of foods served in the canteen, providing fitness facilities, or nudges to promote taking the stairs for example. Workplace health promotion programs may target the promotion of healthy lifestyle behaviors, as these have been recognized as important modifiable risk factors for several chronic diseases. For example, unhealthy diets, sedentary lifestyles, obesity, and smoking have been identified as important contributing factors for chronic diseases $(9,10)$.

A systematic review that summarizes the evidence from reviews on the effect of workplace interventions targeting health promotion to improve health outcomes that predict the onset of chronic diseases is currently lacking. In light of the high prevalence of chronic dis-

Table 1. Literature search in www.embase.com.

\begin{tabular}{l}
\hline Search Embase.com \\
\#30 \#28 OR \#29 121 \\
\#29 \#27 AND ([cochrane review]/lim OR [systematic review]/lim OR [meta \\
analysis]/lim) 78 \\
\#28 \#27 AND 'Review'/it 90 \\
\#27 \#13 OR \#18 OR \#20 OR \#21 OR \#23 OR \#24) AND [2009-2018]/py AND \\
[english]/lim 991 \\
\#26 (\#13 OR \#18 OR \#20 OR \#21 OR \#23 OR \#24) AND [2009-2018]/py 1051 \\
\#25 \#13 OR \#18 OR \#20 OR \#21 OR \#23 OR \#24 2139 \\
\#24 \#12 AND \#17 AND \#22 \\
\#23 \#10 AND \#12 AND \#22 \\
\#22 'mood disorder'/lexp/mj \\
\#21 \#19 AND \#12 AND \#17 \\
\#20 \#19 AND \#10 AND \#12 \\
\#19 'physical disease by body function'/exp/mj \\
\#18 (\#5 OR \#11) AND \#12 AND \#17 \\
\#17 \#14 OR \#15 OR \#16 \\
\#16 nudging*:ti OR counsel*:ti OR educat*:ti \\
\#15 'education'/exp/mj \\
\#14 'counseling'/lexp/mj \\
\#13 (\#5 OR \#11) AND \#10 AND \#12 \\
\#12 \#6 OR \#7 OR \#8 OR \#9 \\
\#11 \#3 OR \#4 \\
\#10 \#1 OR \#2 \\
\#9 'worker'/exp/mj OR worker*:ti OR employe*:ti OR worksite*:ti OR \\
workplace*:ti \\
\#8 'occupational disease'/exp/mj \\
\#7 'work environment'/exp/mj \\
\#6 'workplace'/exp/mj \\
\#5 'physical disease by anatomical structure'/exp/mj \\
\#4 'chronic disease'/exp \\
\#3 chronic*:ti \\
\#2 intervention*:ti \\
\#1 'intervention study'/exp \\
\hline
\end{tabular}

eases, and the role of the workplace to promote health among workers, a joint action CHRODIS-PLUS work package was initiated to develop a toolkit to support employers in understanding the benefits of health promotion and prevention of chronic diseases to enhance the health and wellbeing of the employees, who are healthy, at risk, or already suffer from a chronic disease. As a first step, this meta-review was performed to systematically summarize the available evidence on the effectiveness of worksite health promotion interventions on physical and mental health outcomes that are related to chronic diseases. For the purpose of this review, the focus was on a selection of chronic diseases, ie, type 2 diabetes mellitus (T2DM), cardiovascular diseases (CVD), and mental health and musculoskeletal disorders, given their high disease burden and lifestyle-relatedness.

\section{Methods}

The review was carried out and reported following the Preferred Reporting Items for Systematic Reviews and Meta-Analyses (PRISMA) guidelines (11).

\section{Literature search}

A search for reviews published between January 2009 and February 2018 was performed in electronic databases, ie, www.embase.com (ie, Medline and Embase), PsycINFO, and the Cochrane Library. An experienced librarian assisted in the search strategy and performed the search strategy in the databases. Key terms used in the search strategy referred to the study population or setting, intervention, and outcome under study, and thus included synonyms of terms such as 'workplace', 'worker', 'intervention', 'health promotion', 'lifestyle', 'chronic disease', 'diabetes', musculoskeletal disorders', in combination with 'review' or a synonym thereof. An example of the search strategy in www.embase.com is found in table 1. In addition, the reference lists of the included reviews were checked for additional relevant reviews.

\section{Selection of reviews}

Two reviewers independently screened all titles and abstracts retrieved from the search strategy. The records were screened on the inclusion criteria, including the type of design (review), study population (working population), type of intervention (health promotion), and the outcome under study. Reviews were eligible for inclusion if they studied the effectiveness of health promotion interventions targeting a working population. The outcome under review had to be a health outcome 
that is related to (the prevention of) one of the following chronic diseases: T2DM, CVD, musculoskeletal disorders, or mental health problems. For T2DM and CVD, these included metabolic risk factors, such as elevated blood lipids, cholesterol or systolic blood pressure. For musculoskeletal and mental health disorders, the (selfreported or diagnosed) musculoskeletal or mental health outcomes were included, and could involve a variety of musculoskeletal regions (eg, back, shoulder, knee) and mental health problems (eg, anxiety, depression). Reviews that were primarily focused on treatment of the chronic diseases or work participation with chronic diseases were excluded. The initial screening of the titles and abstracts were discussed between the two reviewers to achieve a list of papers, of which the full-text was retrieved. Then, the two reviewers independently read the full-texts to make the final selection.

\section{Quality appraisal}

The methodological quality of the included reviews was evaluated using AMSTAR (A MeaSurement Tool to Assess systematic Reviews) $(12,13)$. AMSTAR has shown to be a reliable and valid tool for the assessment of the methodological quality of systematic reviews (12) and consists of 11 criteria (13). Table 2 describes all items and the operationalization of the items. For example, two items (\#7 and \#8) concerned the scientific quality of the included studies, where item 7 was scored positively if a quality assessment tool was used. In case

Table 2. Description of the AMSTAR checklist and the operationalization of the items (13).

1 Was an 'a priori' design provided?

The research question and inclusion criteria should be established before the conduct of the review.

Note: Need to refer to a protocol, ethics approval, or pre-determined/a priori published research objectives to score a "yes."

2 Was there duplicate study selection and data extraction?

There should be at least two independent data extractors and a consensus procedure for disagreements should be in place.

Note: 2 people do study selection, 2 people do data extraction, consensus process or one person checks the other's work.

3 Was a comprehensive literature search performed?

At least two electronic sources should be searched. The report must include years and databases used (e.g., Central, EMBASE, and MEDLINE). Key words and/ or MESH terms must be stated and where feasible the search strategy should be provided. All searches should be supplemented by consulting current contents, reviews, textbooks, specialized registers, or experts in the particular field of study, and by reviewing the references in the studies found.

Note: If at least 2 sources + one supplementary strategy used, select "yes" (Cochrane register/Central counts as 2 sources; a grey literature search counts as supplementary).

$4 \quad$ Was the status of publication (i.e. grey literature) used as an inclusion criterion?

The authors should state that they searched for reports regardless of their publication type. The authors should state whether or not they excluded any reports (from the systematic review), based on their publication status, language etc.

Note: If review indicates that there was a search for "grey literature" or "unpublished literature," indicate "yes." SIGLE database, dissertations, conference proceedings, and trial registries are all considered grey for this purpose. If searching a source that contains both grey and non-grey, must specify that they were searching for grey/unpublished lit.

$5 \quad$ Was a list of studies (included and excluded) provided? A list of included and excluded studies should be provided.

Note: Acceptable if the excluded studies are referenced. If there is an electronic link to the list but the link is dead, select "no."

6 Were the characteristics of the included studies provided?

In an aggregated form such as a table, data from the original studies should be provided on the participants, interventions and outcomes. The ranges of characteristics in all the studies analyzed e.g., age, race, sex, relevant socioeconomic data, disease status, duration, severity, or other diseases should be reported Note: Acceptable if not in table format as long as they are described as above

$7 \quad$ Was the scientific quality of the included studies assessed and documented?

'A priori' methods of assessment should be provided (e.g., for effectiveness studies if the author(s) chose to include only randomized, double-blind, placebo controlled studies, or allocation concealment as inclusion criteria); for other types of studies alternative items will be relevant.

Note: Can include use of a quality scoring tool or checklist, e.g., Jadad scale, risk of bias, sensitivity analysis, etc., or a description of quality items, with some kind of result for EACH study ("low" or "high" is fine, as long as it is clear which studies scored "low" and which scored "high"; a summary score/range for all studies is not acceptable).

8 Was the scientific quality of the included studies used appropriately in formulating conclusions?

The results of the methodological rigor and scientific quality should be considered in the analysis and the conclusions of the review, and explicitly stated in formulating recommendations.

Note: Might say something such as "the results should be interpreted with caution due to poor quality of included studies." Cannot score "yes" for this question if scored "no" for question 7.

9 Were the methods used to combine the findings of studies appropriate?

For the pooled results, a test should be done to ensure the studies were combinable, to assess their homogeneity (i.e., Chi-squared test for homogeneity, I2) If heterogeneity exists a random effects model should be used and/or the clinical appropriateness of combining should be taken into consideration (i.e., is it sensible to combine?).

Note: Indicate "yes" if they mention or describe heterogeneity, i.e., if they explain that they cannot pool because of heterogeneity/variability between interventions.

10 Was the likelihood of publication bias assessed?

An assessment of publication bias should include a combination of graphical aids (e.g., funnel plot, other available tests) and/or statistical tests (e.g., Egger regression test, Hedges-Olken).

Note: If no test values or funnel plot included, score "no". Score "yes" if mentions that publication bias could not be assessed because there were fewer than 10 included studies.

11 Was the conflict of interest included?

Potential sources of support should be clearly acknowledged in both the systematic review and the included studies.

Note: To get a "yes," must indicate source of funding or support for the systematic review AND for each of the included studies. 
the quality scoring was considered in the analysis, the conclusions of the review, and explicitly stated in formulating recommendations, item 8 was scored positively as well. Each criterion could be scored as yes (1), no (0), or not applicable, yielding a total score between $0-11$. The two reviewers (blinded) independently scored these items for each review included. Afterwards, a meeting took place to discuss and explain their scorings and achieve consensus in case of discrepancies. If consensus could not be reached, a third reviewer was consulted. Based on the scorings, reviews were classified as of high or low quality. If $>50 \%$ of the criteria was rated positively (score of $\geq 6$ points), the review was considered to be of high quality, otherwise, it was considered to be of low quality (scoring $0-5$ points) $(14,15)$.

\section{Data extraction and synthesis of evidence}

Two reviewers extracted the data, each doing half of the reviews. A standard format was used to describe the first author, year of publication, type of review, study design of studies included, number of studies included, study population, interventions under study, outcome measures, main results and the authors' conclusions. Uncertainties were discussed and solved between the two reviewers.

The synthesis of the evidence was based on a bestevidence system used in a previously published systematic review of workplace interventions, consisting of four levels (16): (i) strong evidence $(* * *)$ in case of $>1$ high-quality reviews with consistent outcomes; (ii) moderate evidence $(* *)$ in case of 1 high-quality and $\geq 1$ low-quality reviews with consistent outcomes; (iii) limited evidence $(*)$ in case of only 1 high-quality or $>1$ low-quality reviews, all with consistent outcomes; (iv) no evidence in case of only 1 low-quality review, or inconsistent results of the reviews.

Consistency was defined if $\geq 75 \%$ of the reviews showed results in the same direction (14).

\section{Results}

\section{Review selection}

The literature search identified 374 papers (figure 1). After screening all titles and abstracts, 37 reviews were considered for full-text assessment. Of these, 14 reviews were excluded for various reasons. Consequently, 23 reviews were included in our meta-review.

\section{Quality of the reviews}

The two reviewers initially disagreed in $10 \%$ of the reviews. As all disagreements were resolved by discussion, a third reviewer was not consulted. Of the

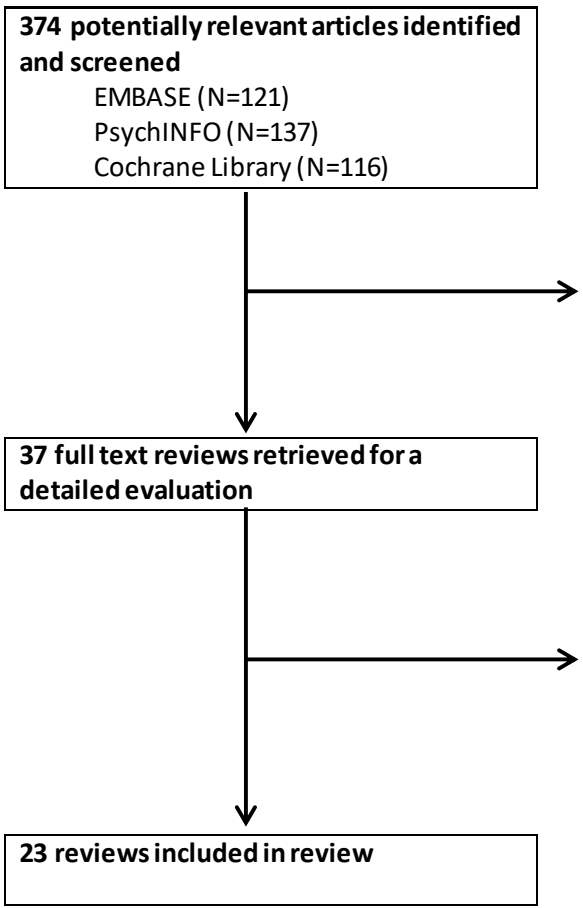

374 potentially relevant articles identified

EMBASE $(\mathrm{N}=121)$

PsychINFO ( $\mathrm{N}=137)$

Cochrane Library $(\mathrm{N}=116)$
337 articles excluded based on title and abstract

45 duplicate articles

292 articles did not meet the inclusion

criteria

\section{4 reviews excluded}

2 reviews are not exclusively targeted to a

working population $(47,48)$

1 review does not describe any included

outcome (49)

3 reviews of reviews $(16,44,45)$

3 reviews report the results and

conclusions for included outcomes and

other outcomes altogether (50-52)

2 most studies in reviews describe tertiary

prevention interventions $(53,54)$

2 the effectiveness of interventions is not

the objective of these reviews $(55,56)$

1 no integration of effects of interventions

in this review, all results were separately

reported (57)
Figure 1. Flow diagram for inclusion of reviews. 
Table 3. Scores on the AMSTAR checklist for all included reviews.

\begin{tabular}{|c|c|c|c|c|c|c|c|c|c|c|c|c|}
\hline & $\begin{array}{l}\text { A priori } \\
\text { design }\end{array}$ & $\begin{array}{l}\text { Duplicate } \\
\text { study } \\
\text { selection } \\
\text { and data } \\
\text { extraction }\end{array}$ & $\begin{array}{l}\text { Compre- } \\
\text { hensive } \\
\text { literature } \\
\text { search }\end{array}$ & $\begin{array}{l}\text { Status } \\
\text { publication } \\
\text { used as } \\
\text { inclusion } \\
\text { criterion }\end{array}$ & $\begin{array}{l}\text { List of } \\
\text { included } \\
\text { \& excluded } \\
\text { studies }\end{array}$ & $\begin{array}{l}\text { Charact- } \\
\text { eristics of } \\
\text { included } \\
\text { studies }\end{array}$ & $\begin{array}{l}\text { Scientific } \\
\text { quality } \\
\text { assessed \& } \\
\text { documented }\end{array}$ & $\begin{array}{l}\text { Scientific } \\
\text { quality } \\
\text { appropri- } \\
\text { ately used in } \\
\text { conclusions }\end{array}$ & $\begin{array}{l}\text { Appropriate } \\
\text { methods used } \\
\text { to combine } \\
\text { studies' } \\
\text { findings }\end{array}$ & $\begin{array}{l}\text { Publi- } \\
\text { cation } \\
\text { bias }\end{array}$ & $\begin{array}{l}\text { Conflicts } \\
\text { of interest } \\
\text { statement }\end{array}$ & $\begin{array}{l}\text { High a } \\
\text { quality }\end{array}$ \\
\hline $\begin{array}{l}\text { Anderson } \\
\text { et al, } 2009 \text { (28) }\end{array}$ & No & No & Yes & No & Yes & Yes & Yes & No & Yes & No & No & Low \\
\hline $\begin{array}{l}\text { Archer et al, } \\
2011 \text { (29) }\end{array}$ & No & No & Yes & Yes & No & No & Yes & Yes & Yes & No & No & Low \\
\hline $\begin{array}{l}\text { Carolan et al, } \\
2017 \text { (17) }\end{array}$ & Yes & No & Yes & Yes & No & Yes & Yes & No & Yes & Yes & No & High \\
\hline $\begin{array}{l}\text { Chu et al, } \\
2014 \text { (17) }\end{array}$ & No & No & Yes & No & No & Yes & Yes & Yes & No & No & No & Low \\
\hline $\begin{array}{l}\text { Conn et al, } \\
2009 \text { (18) }\end{array}$ & No & No & Yes & Yes & No & No & No & No & Yes & Yes & No & Low \\
\hline $\begin{array}{l}\text { Fernandez et } \\
\text { al, } 2014 \text { (30) }\end{array}$ & No & No & Yes & No & No & Yes & Yes & Yes & No & No & No & Low \\
\hline $\begin{array}{l}\text { Groeneveld et } \\
\text { al, } 2010 \text { (14) }\end{array}$ & No & No & Yes & No & No & Yes & Yes & Yes & No & No & No & Low \\
\hline $\begin{array}{l}\text { Hafez et al, } \\
2017 \text { (25) }\end{array}$ & No & Yes & Yes & No & No & Yes & No & $\mathrm{N} / \mathrm{A}$ & No & No & No & Low \\
\hline $\begin{array}{l}\text { Kent Anger et } \\
\text { al, } 2015 \text { (26) }\end{array}$ & No & Yes & Yes & No & No & Yes & No & $\mathrm{N} / \mathrm{A}$ & No & No & No & Low \\
\hline $\begin{array}{l}\text { Krungkraipetch } \\
\text { et al, } 2012 \text { (35) }\end{array}$ & h No & Yes & Yes & No & No & Yes & Yes & Yes & Yes & No & No & High \\
\hline $\begin{array}{l}\text { Kwak et al } \\
2014 \text { (27) }\end{array}$ & No & Yes & Yes & No & No & Yes & Yes & Yes & No & No & No & Low \\
\hline $\begin{array}{l}\text { Martin et al } \\
2009 \text { (19) }\end{array}$ & No & Yes & Yes & No & No & Yes & No & $\mathrm{N} / \mathrm{A}$ & Yes & Yes & No & Low \\
\hline $\begin{array}{l}\text { Mehta et al, } \\
2013 \text { (31) }\end{array}$ & No & Yes & Yes & Yes & No & Yes & No & $\mathrm{N} / \mathrm{A}$ & No & No & No & Low \\
\hline $\begin{array}{l}\text { Montano et } \\
\text { al, } 2014 \text { (20) }\end{array}$ & No & No & Yes & No & No & Yes & Yes & No & Yes & Yes & No & Low \\
\hline $\begin{array}{l}\text { Power et al, } \\
2013 \text { (21) }\end{array}$ & Yes & Yes & Yes & No & Yes & Yes & Yes & Yes & Yes & Yes & No & High \\
\hline $\begin{array}{l}\text { Tam et al, } \\
2018 \text { (32) }\end{array}$ & No & Yes & Yes & No & No & Yes & Yes & Yes & Yes & No & No & High \\
\hline $\begin{array}{l}\text { Tan et al, } \\
2014 \text { (22) }\end{array}$ & No & No & Yes & No & No & Yes & Yes & Yes & Yes & Yes & No & High \\
\hline $\begin{array}{l}\text { Tullar et al, } \\
2010 \text { (36) }\end{array}$ & No & Yes & Yes & No & No & Yes & Yes & Yes & Yes & No & No & High \\
\hline $\begin{array}{l}\text { van Eerd et } \\
\text { al, } 2016 \text { (37) }\end{array}$ & No & Yes & Yes & No & No & No & No & Yes & Yes & Yes & No & Low \\
\hline $\begin{array}{l}\text { van Niekerk et } \\
\text { al, } 2012 \text { (38) }\end{array}$ & No & Yes & Yes & No & No & Yes & Yes & Yes & Yes & No & No & High \\
\hline $\begin{array}{l}\text { Verbeek et al, } \\
2011 \text { (23) } \\
\text { Verweij et al, }\end{array}$ & No & Yes & Yes & No & Yes & Yes & Yes & Yes & Yes & Yes & No & High \\
\hline $2011(24)$ & No & Yes & Yes & No & No & Yes & Yes & Yes & Yes & Yes & No & High \\
\hline $\begin{array}{l}\text { Vuillemin et } \\
\text { al, } 2011 \text { (33) }\end{array}$ & No & No & Yes & No & No & Yes & No & Yes & Yes & No & No & Low \\
\hline
\end{tabular}

a High quality studies were defined by $\geq 6$ points on the AMSTAR checklist.

23 reviews, 9 were of high quality (table 3). Although all reviews reported their funding for the review, they lacked the reporting of source of funding or support for each of the included studies. Thereby, none of the reviews scored positively on the item that involved the conflict of interest. Only 3 reviews met the criterion with respect to the listed in- and excluded studies, and only 4 out of the 23 reviews explicitly stated that they included grey literature.

\section{Description of reviews}

Most reviews $(\mathrm{N}=20)$ were systematic, of which 8 (17-24) performed a meta-analysis. The remaining 3
(25-27) concerned a narrative or scoping review. With respect to the metabolic risk factors for T2DM and CVD, most reviews $(14,18,20,21,24-33)$ evaluated the effect of workplace health promotion interventions on weight-related outcomes, such as body weight, body mass index (BMI), percentage of body fat, waist circumference. The remaining metabolic risk factors, such as lipid measures, blood glucose, and blood pressure were also studied in 5 reviews $(14,18,25-27)$. Defined by depression, anxiety or stress, mental health as outcome was studied in 6 reviews $(17-20,22,34)$. Another $6(20,23,35-38)$ summarized the effect of workplace interventions on the prevention of musculoskeletal disorders. 
Table 4. Description of the reviews that studied the effect on weight-related outcomes. [RCT=randomized controlled trial; $\mathrm{Cl}=$ confidence interval; $\mathrm{MD}=$ mean different; $\mathrm{SMD}=$ standardized mean difference; $\mathrm{IQR}=$ interquartile range; $\mathrm{CVD}=$ cardiovascular disease.]

\begin{tabular}{|c|c|c|c|}
\hline Review & $\begin{array}{l}\text { Number and } \\
\text { type of studies }\end{array}$ & Type of intervention & Author's conclusion \\
\hline $\begin{array}{l}\text { Power et al, } \\
2013(21)^{a}\end{array}$ & $\begin{array}{l}\mathrm{N}=13(\mathrm{RCT}) ; \\
\mathrm{N}=7 \text { with available data } \\
\text { for meta-analysis }\end{array}$ & $\begin{array}{l}\text { Workplace based diet and/or physical activity } \\
\text { interventions }\end{array}$ & $\begin{array}{l}6 \text { interventions reported statistically significant effects on weight related } \\
\text { outcomes. Pooling across the } 5 \text { studies with follow-up }<12 \text { months showed } \\
\text { a greater reduction in body weight }(-2.03 \mathrm{~kg}, 95 \% \mathrm{Cl}-3.92--0.15 \mathrm{~kg}) \text { than } \\
\text { controls. No significant difference in body weight change }(-2.60,95 \% \mathrm{Cl} \\
-5.37--0.17 \mathrm{~kg}) \text { across the } 3 \text { studies with } \geq 12 \text { months follow-up). } \\
\text { Workplace interventions targeted both physical activity and diet resulted the } \\
\text { largest differences in weight reduction. }\end{array}$ \\
\hline $\begin{array}{l}\text { Tam et al, } \\
2018(32)^{\text {a }}\end{array}$ & $\mathrm{N}=11(\mathrm{RCT})$ & $\begin{array}{l}\text { Onsite workplace multicomponent lifestyle } \\
\text { (exercise and diet) interventions }\end{array}$ & $\begin{array}{l}5 \text { of the } 11 \text { studies reported a statistically significant reduction in BMI lasting } \\
1-2 \text { years; the remaining reported no significant reduction. } \\
\text { Some evidence demonstrating long-term effectiveness of multicomponent } \\
\text { lifestyle interventions in the workplace targeting obesity. Studies showing } \\
\text { significant BMI reductions were of high intensity or included a specific moti- } \\
\text { vational component. }\end{array}$ \\
\hline
\end{tabular}

Verweij et $\quad \mathrm{N}=43(\mathrm{RCT}) ; \quad$ Onsite workplace multicomponent lifestyle

al, $2011 \quad \mathrm{~N}=22$ in meta-analysis (exercise and diet) interventions
Moderate quality of evidence that workplace physical activity and nutrition interventions significantly reduce body weight (MD - $1.19 \mathrm{~kg}, 95 \% \mathrm{Cl}-1.64-$ $-0.74)$, BMI (MD: $-0.34 \mathrm{~kg} / \mathrm{m}^{2}, 95 \% \mathrm{Cl}:-0.46--0.22$ ) and body fat $\%$ (MD $-1.12 \%, 95 \% \mathrm{Cl}-1.86--0.38)$. Low quality of evidence that interventions targeting physical activity only reduced body weight by MD: $-1.08 \mathrm{~kg}, 95 \% \mathrm{Cl}$ $-1.79--0.36)$

To prevent weight gain, workplace physical activity and nutrition interventions that contain an environmental component are recommended.

Only RCT included: SMD weight: -2.8 pounds $(95 \% \mathrm{Cl}-4.63--0.96)$ at 6-12month follow-up (9 RCT); SMD BMI -0.47 (95\% Cl-1.02- -0.2) at 6-12 months ( 6 RCT). On basis of all available study designs: Mean change weight: -3.15 pounds (range $-14.77-3.6$ ) at 12 months ( 12 studies); mean change BMI -0.40 (range $-1.57-0.3$ ) points at $6-9$ months (12 studies), -0.02 points (range $-0.9-0.5$ ) at 12 months ( 12 studies); mean change body fat $\%:-1.03$ (range $-2.56-1.2$ ) at 6-9 months (13 studies).

There is evidence of a modest reduction in weight as a result of worksite health promotion programs aimed at improving nutrition, physical activity, or both.

Archer et $\quad \mathrm{N}=136$ (various study $\quad$ Three strategies: (i) environmental and policy al, 2011 designs) strategies to change the structure of physical (29) and organizational environments to provide healthy food, convenient opportunities for physical activity, and incentives; (ii) informational and educational strategies to change employees' knowledge and attitudes about the benefits of healthy nutritional habits and opportunities for physical activity; and (iii) behavioral strategies to teach employees skills studies).

to successfully adopt and maintain behavioral changes and to create social environments

that facilitate and enhance behavioral change.

Conn et al, $\quad \mathrm{N}=138$ (studies with 2009 (18) varied designs) Interventions aimed to improve physical activity

6 promising practices identified, with sufficiency of evidence. The following effect sizes (ES) were reported on basis of greatest suitability of study design: Enhanced access to opportunities for physical activity combined with health education (ES -3.24\%, IQR - 7.24- - 3.09\%, 5 studies); Exercise prescriptions alone (ES -2.45\%, IQR -3.56- -1.69\%, 10 studies); Multicomponent educational practices (ES -2.24, IQR -3.57- -0.99\%, 13 studies); Weight loss competitions and incentives (ES $-2.66 \%$, IQR $-5.34--1.22 \%, 6$ studies); Behavioral practices with incentives (ES - 3.72, IQR -4.69- -1.67\%, 8 studies); Behavioral practices without incentives (ES -2.33\%, IQR -6.69- $-0.55 \%, 26$ group pre-post 0.07 (95\% Cl 0.03- 0.11); treatment pre-post $0.13(95 \% \mathrm{Cl}$ $0.10-0.17)$

Some interventions improve physical activity in some subjects, which in turn may improve selected health outcomes, but significant heterogeneity requires cautious interpretation of findings.

Fernandez $\quad \mathrm{N}=8$ (RCT, non-RCT) et al, 2014

Interventions included changes in the food 5 studies: body weight and/or fat decrease more in intervention than in con(30) and physical activity environment in the work place (e.g., cafeteria interventions, establishing walking routes), with or without additional individual-level approaches, with or without changes in policies or programs promoting any aspect of the causal pathways to obesity prevention and control.

Groeneveld $\mathrm{N}=31$ (RCT);

et al, $2010 \mathrm{~N}=20$ with body

(14) weight/BMI as outcome, $\mathrm{N}=3$ with body fat as outcome

Hafez et al, N=13 (2 RCT, 1 non-

2017 (25) RCT, 1 cluster RCT, 3 single group time series, 2 single group pre-post, 1 multi-group

Worksite lifestyle (physical activity and/or healthy diet) or health promotion interventions (such as individual counseling, group education, or self-help)

Evidence-based Diabetes Prevention Program DDP: weight loss ranged from 0.4 to $5.1 \mathrm{~kg}$ at 3 to 6 months ( 8 studies) and (DPP) $(\mathrm{N}=10)$ or a non-DPP intervention $(\mathrm{N}=3)$ from 1.43 to $4.9 \mathrm{~kg}$ at 7 to 12 months ( 6 studies).

that aimed to prevent type 2 diabetes (T2DM) pre-post, 3 cohort studies)

sites those measures decreased while in control sites increased.

2 studies: BMI increased more in intervention than in control worksites.

1 study: no quantitative information on the measure of effect. The magnitude of the measure of effect was $<1 \mathrm{BMl}$ unit difference in all studies with quantitative reporting.

The evidence has low risk of bias since $50 \%$ of the studies were deemed to have a low risk of bias. Among the studies evaluated with a low risk of bias, the effect on the measures of body weight or fat was modest and sometimes in the unexpected direction.

Strong evidence for a beneficial effect on overall body fat. No evidence for an effect on body weight.

Non-DDP interventions: minimal changes in weight loss at 6 and 12 months (2 studies).

Workplace interventions to prevent T2DM are most effective when they utilize the structured, evidence-based DPP curriculum with minimal modifications. 
Table 4. continued.

\begin{tabular}{|c|c|c|c|}
\hline Review & $\begin{array}{l}\text { Number and type of } \\
\text { studies }\end{array}$ & Type of intervention & Author's conclusion \\
\hline $\begin{array}{l}\text { Kent Anger } \\
\text { et al, } 2015 \\
(26)\end{array}$ & $\begin{array}{l}\mathrm{N}=17 \text { ( } 9 \text { RCT, } 7 \text { quasi- } \\
\text { experimental design, } 1 \\
\text { multiple group nonex- } \\
\text { perimental design) } \\
\mathrm{N}=5 \text { with weight-relat- } \\
\text { ed outcome }\end{array}$ & $\begin{array}{l}\text { Total worker health (TWH) interventions: both } \\
\text { traditional occupational safety and/or health } \\
\text { (OSH, health protection) and wellness and/or } \\
\text { well-being should be addressed in the same } \\
\text { intervention }\end{array}$ & $\begin{array}{l}\text { Weight significantly changed in } \geq 3 \text { TWH interventions. Results for weight } \\
\text { change were inconsistent in } 5 \text { studies. } \\
\text { Insufficient evidence to identify best practice interventions. All but one of the } \\
17 \text { TWH intervention programs improved outcomes that are risk factors for in- } \\
\text { juries and/or chronic diseases and } 4 \text { interventions improved } \geq 10 \text { risk factors. }\end{array}$ \\
\hline $\begin{array}{l}\text { Kwak et al, } \\
2014(27)\end{array}$ & $\mathrm{N}=10(\mathrm{RCT})$ & $\begin{array}{l}\text { Interventions implemented by the occupation- } \\
\text { al health services to promote physical activity } \\
\text { and/or healthy dietary behavior }\end{array}$ & $\begin{array}{l}\text { Overall study results on the effectiveness of health promotion through the OHS } \\
\text { are promising, especially with regard to interventions containing counseling } \\
\text { to individuals with one or more CVD risk factors, either as single component or } \\
\text { combined with an environmental component. The good-quality studies report- } \\
\text { ed positive intervention effects on biological risk factors for CVD. }\end{array}$ \\
\hline $\begin{array}{l}\text { Mehta et al, } \\
2013 \text { (31) }\end{array}$ & $\begin{array}{l}\mathrm{N}=5 \text { (1 RCT, } 4 \text { pre-post } \\
\text { designs) }\end{array}$ & Physical activity and healthy eating & $\begin{array}{l}\text { Cohen's d } 0.09-0.603 \text {. } \\
\text { Significant outcomes in all } 5 \text { interventions, } 3 \text { found significant outcomes in } \\
\text { BMl, } 3 \text { in weight, } 2 \text { in waist circumference, and } 1 \text { in waist-to-hip ratio. }\end{array}$ \\
\hline $\begin{array}{l}\text { Montano } \\
\text { et al, } 2014 \\
(20)\end{array}$ & $\mathrm{N}=12(\mathrm{RCT})$ & $\begin{array}{l}\text { Cognitive behavioral, ergonomics, health } \\
\text { education, health promotion, physical activity, } \\
\text { stress management }\end{array}$ & $\begin{array}{l}\text { SMD: BMI: }-0.16(95 \% \mathrm{Cl}-0.29--0.02) \text {. Workplace interventions can have } \\
\text { small, but positive effects on health outcomes. }\end{array}$ \\
\hline $\begin{array}{l}\text { Vuillemin } \\
\text { et al, } 2011 \\
\text { (33) }\end{array}$ & $\begin{array}{l}\mathrm{N}=33 \text { (RCT, controlled } \\
\text { before and after, } \\
\text { controlled non-RCT) }\end{array}$ & $\begin{array}{l}\text { Workplace physical activity intervention in } \\
\text { Europe aimed at primary prevention; } 6 \text { inter- } \\
\text { vention categories: (i) counselling, (ii) exercise } \\
\text { training, (iii) active commuting, (iv) walking } \\
\text { interventions, (v) stair use, (vi) multicompo- } \\
\text { nent interventions }\end{array}$ & $\begin{array}{l}\text { No or inconclusive evidence for obesity-related outcomes for all physical ac- } \\
\text { tivity intervention categories. } \\
\text { Active commuting and exercise training appear as promising approaches to } \\
\text { promote physical activity or fitness in the workplace. The effect of interven- } \\
\text { tions on obesity-related outcomes remains to be further investigated. }\end{array}$ \\
\hline
\end{tabular}

a High quality review.

\section{Effect of interventions on weight-related outcomes}

Of the 14 reviews that summarized the effect of workplace health promotion programs on weight-related outcomes, only $3(21,24,32)$ were of high quality (table 4$)$. Main outcomes under study included body weight, body mass index (BMI), and body fat percentage. Except for 2 $(25,26)$, all reviews evaluated studies that targeted the promotion of physical activity and/or healthy diet. These lifestyle behavior interventions however used different strategies, including individually-based approaches and environmental adjustments. A broader approach, such as total worker health interventions in which both health protection and wellness were addressed, was evaluated in 2 reviews $(25,26)$. All 3 high quality reviews $(21,24$, 32) exclusively included randomized controlled trials (RCT) that evaluated the effect of workplace lifestyle interventions targeting diet and/or physical activity. Of these, $2(21,24)$ also performed a meta-analysis of a subsample of their included RCT. Overall, some positive results were found on weight-related outcomes. Verweij et al (24) concluded moderate quality evidence for a favorable effect of workplace physical activity and diet interventions on body weight, BMI, and body fat percentage, but low quality evidence for an effect on body weight of interventions that focused on physical activity only. Furthermore, they recommended the addition of an environmental component to prevent weight gain, which was based on subgroup analyses. Based on the pooled results, Power et al (21) also recommended workplace interventions that targeted both energy balance related behaviors (physical activity and diet) for weight reduction. The third high quality review (32) also concluded some evidence for a positive long-term effect of multicomponent lifestyle interventions targeting obesity and additionally recommended interventions of high intensity or including a motivational component.

The remaining 11 reviews, which were of low quality, overall showed some evidence for beneficial effects on weight-related outcomes although some reported mixed results for different weight-related outcomes. Some reviews recommended specific intervention types to the prevention of weight gain. Archer et al (29), for example, identified six promising practices with sufficient evidence for beneficial effects, including enhanced access to opportunities for physical activity in combination with health education, exercise prescriptions, multicomponent educational practices, weight loss competitions and incentives, and behavioral practices both with and without incentives.

In conclusion, as the three high quality reviews all found consistently favorable effects of lifestyle interventions, there is strong evidence for a positive effect of workplace health promotion targeting physical activity and/or diet on weight-related outcomes.

\section{Effect of interventions on remaining metabolic risk}

All 5 reviews reporting on the evidence on metabolic risk factors were rated as of low quality (table 5). A variety of metabolic risk factors were studied, including lipid measures, glucose, and blood pressure. Each of the reviews summarized the evidence on multiple metabolic risk factors. For example, Conn et al (18) studied lipids 
Table 5. Description of the reviews that studied the effect on remaining metabolic risk outcomes. [Cl=confidence interval; $C V D=c a r d i o v a s c u l a r ~ d i s e a s e$.

\begin{tabular}{|c|c|c|c|}
\hline Review & $\begin{array}{l}\text { Number and type } \\
\text { of studies }\end{array}$ & Type of intervention & Author's conclusion \\
\hline $\begin{array}{l}\text { Conn et al, } \\
2009 \text { (18) }\end{array}$ & $\begin{array}{l}\mathrm{N}=138 \text { (stud- } \\
\text { ies with varied } \\
\text { designs) }\end{array}$ & $\begin{array}{l}\text { Interventions aimed to } \\
\text { improve physical activity }\end{array}$ & $\begin{array}{l}\text { Effect sizes: } \\
\text { Diabetes risk (two-group post-test } 0.57(95 \% \mathrm{Cl} 0.06-1.90) \text {; two-group pre-post } 0.51(95 \% \mathrm{Cl} \\
0.27-0.53) \text {; treatment pre-post } 0.47(95 \% \mathrm{Cl} 0.38-0.56) \text {. } \\
\text { Lipids (two-group post-test } 0.13(95 \% \mathrm{Cl} 0.02-0.24) ; \text { two-group pre-post } 0.17(95 \% \mathrm{Cl} 0.01- \\
0.33) \text {; treatment pre-post } 0.12(95 \% \mathrm{Cl} 0.08-0.17) \text {. } \\
\text { Some interventions improve physical activity in some subjects, which in turn may improve select- } \\
\text { ed health outcomes, but significant heterogeneity requires cautious interpretation of findings. }\end{array}$ \\
\hline $\begin{array}{l}\text { Groeneveld et } \\
\text { al, } 2010 \text { (14) }\end{array}$ & $\begin{array}{l}\mathrm{N}=31(\mathrm{RCT}) \\
\mathrm{N}=18 \text { for blood } \\
\text { pressure, } \mathrm{N}=21 \\
\text { for serum lipids, } \\
\mathrm{N}=3 \text { for blood } \\
\text { glucose }\end{array}$ & $\begin{array}{l}\text { Worksite lifestyle (physi- } \\
\text { cal activity and/or healthy } \\
\text { diet) or health promotion } \\
\text { interventions (such as in- } \\
\text { dividual counseling, group } \\
\text { education, or self-help) }\end{array}$ & No evidence for an effect on blood pressure, serum lipid profile, blood glucose, and triglycerides. \\
\hline $\begin{array}{l}\text { Hafez et al, } \\
2017 \text { (25) }\end{array}$ & $\begin{array}{l}\mathrm{N}=13 \text { ( } 2 \mathrm{RCT}, 1 \\
\text { non-RCT, } 1 \text { clus- } \\
\text { ter RCT, } 3 \text { single } \\
\text { group time series, } \\
2 \text { single group } \\
\text { pre-post, } 1 \text { multi- } \\
\text { group pre-post, } 3 \\
\text { cohort studies) }\end{array}$ & $\begin{array}{l}\text { Evidence-based Diabetes } \\
\text { Prevention Program (DPP) } \\
\text { ( } N=10) \text { or a non-DPP inter- } \\
\text { vention }(\mathrm{N}=3 \text { ) that aimed } \\
\text { to prevent Type } 2 \text { diabetes } \\
\text { (T2DM) }\end{array}$ & $\begin{array}{l}\text { DDP: glycemic change: } 2 \text { studies showed improvement in HbA1c, } 1 \text { study improvement in fasting } \\
\text { blood glucose, and } 1 \text { showed improvement in fasting blood glucose among women, but worsen- } \\
\text { ing among men. } \\
\text { Non-DDP interventions: } 2 \text { studies found reduction in HbA1c at } 12 \text { months, } 1 \text { study found worsen- } \\
\text { ing fasting blood glucose at } 2.5 \text { years. } \\
\text { Workplace interventions to prevent T2DM are most effective when they utilize the structured, } \\
\text { evidence-based DPP curriculum with minimal modifications. }\end{array}$ \\
\hline $\begin{array}{l}\text { Kent Anger et } \\
\text { al, } 2015(26)\end{array}$ & $\begin{array}{l}\mathrm{N}=17 \text { (9 RCT, } 7 \\
\text { quasi-experi- } \\
\text { mental design, } \\
1 \text { multiple group } \\
\text { nonexperimental } \\
\text { design); } \\
\mathrm{N}=3 \text { with blood } \\
\text { pressure as out- } \\
\text { come, } \mathrm{N}=3 \text { with } \\
\text { cholesterol as } \\
\text { outcome }\end{array}$ & $\begin{array}{l}\text { Total worker health (TWH) } \\
\text { interventions: both tradi- } \\
\text { tional occupational safety } \\
\text { and/or health (OSH, health } \\
\text { protection) and wellness } \\
\text { and/or well-being (HP) } \\
\text { should be addressed in the } \\
\text { same intervention }\end{array}$ & $\begin{array}{l}\text { Blood pressure, and cholesterol significantly changed in } \geq 3 \text { TWH interventions. Systolic blood } \\
\text { pressure reductions were reported ranging from }-6 \mathrm{~mm} / \mathrm{Hg} \text { to }-12.79 \mathrm{~mm} / \mathrm{Hg} \text {. Favorable changes } \\
\text { in high density lipoprotein cholesterol and total cholesterol were reported based on } 3 \text { studies. } \\
\text { Insufficient evidence to identify best practice interventions. All but one of the } 17 \text { TWH interven- } \\
\text { tion programs improved outcomes that are risk factors for injuries and/or chronic diseases and } 4 \\
\text { interventions improved } \geq 10 \text {. }\end{array}$ \\
\hline $\begin{array}{l}\text { Kwak et al, } \\
2014 \text { (27) }\end{array}$ & $\mathrm{N}=10(\mathrm{RCT})$ & $\begin{array}{l}\text { Interventions implemented } \\
\text { by the occupational health } \\
\text { services to promote physi- } \\
\text { cal activity and/or healthy } \\
\text { dietary behavior }\end{array}$ & $\begin{array}{l}\text { Overall study results on the effectiveness of health promotion through the OHS are promising, es- } \\
\text { pecially with regard to interventions containing counseling to individuals with one or more CVD } \\
\text { risk factors, either as single component or combined with an environmental component. The } \\
\text { good-quality studies reported positive intervention effects on biological risk factors for CVD. }\end{array}$ \\
\hline
\end{tabular}

measures and the risk for diabetes, the latter defined by fasting glucose and insulin levels. Also, Groeneveld et al (14) and Kwak et al (27) used various risk factors as outcome including lipids, blood pressure, and blood glucose. The promotion of healthy lifestyle behaviors (especially physical activity and healthy diet) was the main intervention component in 3 reviews $(14,18,27)$. The remaining $2(25,26)$ evaluated more comprehensive approaches.

The reviews showed mixed findings with respect to the effect on metabolic risk. To illustrate, the systematic review of RCT of Groeneveld et al (14) concluded no evidence for a positive effect of workplace lifestyle interventions on blood pressure, serum lipid profile, blood glucose, and triglycerides, which was mainly due to inconsistencies between the study findings under review. In contrast, Kwak et al (27), who also studied RCT to the effect of interventions to promote healthy lifestyle behaviors, found that high quality studies reported favorable intervention effects on biological risk factors for cardiovascular diseases (CVD). Furthermore, based on the review of studies that evaluated total worker health interventions, Kent Anger et al (26) showed that all but one of the 17 interventions improved outcomes that are risk factors for injuries and/or chronic diseases. Still, they concluded insufficient evidence to identify best practice interventions.

In sum, because of the inconsistent conclusions of the low quality reviews, there is no evidence for a positive effect of health promotion interventions at the workplace on metabolic risk factors (except for weightrelated outcomes).

\section{Effect of workplace interventions on mental health}

Table 6 describes the studies that examined the effectiveness of workplace interventions on mental health outcomes: 6 reviews $(17-20,22,34)$ summarized the evidence with respect to the effectiveness of worksite health promotion interventions on mental health; 2 (17, 22 ) were of high quality. Mental health was mostly (5 out of 6 reviews) defined by measures including depression and anxiety; 1 review (20) studied the effect of workplace interventions on job stress.

Consistent results were seen in 2 high quality reviews $(17,22)$, with both showing a small positive effect on mental health. Based on a meta-analysis of 21 RCT evaluating the effect of digital mental health 
Table 6. Description of the reviews that studied the effect on mental health outcomes. [Cl=confidence interval.]

\begin{tabular}{|c|c|c|c|}
\hline Review & $\begin{array}{l}\text { Number and type } \\
\text { of studies }\end{array}$ & Type of intervention & Author's conclusion \\
\hline $\begin{array}{l}\text { Carolan et al, } \\
2017(17)^{a}\end{array}$ & $\mathrm{~N}=21$ (RCT) & $\begin{array}{l}\text { Digital mental health interventions: psychologi- } \\
\text { cal interventions aimed at increasing psycho- } \\
\text { logical well-being (eg, by reducing symptoms } \\
\text { of stress or depression) and delivered via the } \\
\text { Internet, mobile technology, or a computer } \\
\text { program. }\end{array}$ & $\begin{array}{l}\text { Standardized mean difference (SMD) for psychological wellbeing: } \mathrm{g}=0.37 \text {, } \\
95 \% \mathrm{CI} 0.23-0.50 \text {. } \\
\text { Digital mental health interventions delivered in the workplace produced a } \\
\text { small positive effect on psychological well-being. }\end{array}$ \\
\hline $\begin{array}{l}\text { Tan et al, } \\
2014(22)^{\text {a }}\end{array}$ & $\mathrm{N}=9$ (RCT) & $\begin{array}{l}\text { Interventions at the workplace aimed at univer- } \\
\text { sal prevention of depression. Most interven- } \\
\text { tions used cognitive behavioral therapy (CBT) } \\
\text { techniques. }\end{array}$ & $\begin{array}{l}\text { The overall effect (SMD) was } 0.16(95 \% \mathrm{Cl} 0.07-0.24) \text { indicating a small pos- } \\
\text { itive effect. A separate analysis of interventions using CBT techniques yielded } \\
\text { a significant SMD of } 0.12 \text { ( } 95 \% \mathrm{Cl} 0.02-0.22) \text {. } \\
\text { Good quality evidence that universally delivered workplace mental health } \\
\text { interventions can reduce the level of depression symptoms among workers; } \\
\text { there is more evidence for the effect of CBT-based interventions than other } \\
\text { interventions. }\end{array}$ \\
\hline $\begin{array}{l}\text { Chu et al, } \\
2014(34)\end{array}$ & $\begin{array}{l}\mathrm{N}=17 \text { (RCT and } \\
\text { quasi-experimen- } \\
\text { tal studies) }\end{array}$ & $\begin{array}{l}\text { Interventions that involved evaluation of the } \\
\text { effectiveness of physical activity interventions } \\
\text { (ie, interventions could be supervised or non- } \\
\text { supervised physical activity, exercise and yoga } \\
\text { programs delivered either at the workplace or } \\
\text { home based). }\end{array}$ & $\begin{array}{l}\text { Two RCT of high quality assessed the effects of physical activity on depressive } \\
\text { symptoms. One found that participants receiving an exercise training plus } \\
\text { behavior modification program significantly reduced depression scores by } \\
-26 \% \text { compared with participants who did not receive the program. The sec- } \\
\text { ond RCT found an improvement in depression scores among participants who } \\
\text { received the exercise training compared with the control group after the 10- } \\
\text { week program, but the difference between the two groups was not significant } \\
\text { There is moderate evidence for the effectiveness of physical activity interven- } \\
\text { tions to improve depression. }\end{array}$ \\
\hline $\begin{array}{l}\text { Conn et al, } \\
2009(18)\end{array}$ & $\begin{array}{l}\mathrm{N}=138 \text { (stud- } \\
\text { ies with varied } \\
\text { designs) }\end{array}$ & $\begin{array}{l}\text { Interventions aimed to improve physical } \\
\text { activity. }\end{array}$ & $\begin{array}{l}\text { Effect sizes (ES) : Mood two-group post-test } 0.13 \text { ( } 95 \% \mathrm{Cl}-0.05-0.31) \text {; two- } \\
\text { group pre-post } 0.21 \text { ( } 95 \% \mathrm{Cl} 0.07-0.36) \text {; treatment pre-post } 0.31(95 \% \mathrm{Cl} \\
0.22-0.40) \text {. } \\
\text { Mean ES for mood ( } 0.13) \text { were positive, indicating better outcomes among } \\
\text { treatment subjects, but these did not reach significance. }\end{array}$ \\
\hline $\begin{array}{l}\text { Martin et al, } \\
2009(19)\end{array}$ & $\begin{array}{l}\mathrm{N}=22 \text {; } \\
\mathrm{N}=17 \text { in meta- } \\
\text { analysis (RCT, } \\
\text { quasi-experimental } \\
\text { studies, pre-post } \\
\text { without control } \\
\text { group) }\end{array}$ & $\begin{array}{l}\text { Psychological interventions (utilized psycho- } \\
\text { education focused on cognitive behavior or } \\
\text { training in coping skills within a stress manage- } \\
\text { ment framework): directly targeting depression } \\
\text { and anxiety symptoms, and health promotion } \\
\text { interventions: indirectly targeting them via risk } \\
\text { factors eg physical activity, poor work environ- } \\
\text { ment and cardiovascular disease. }\end{array}$ & 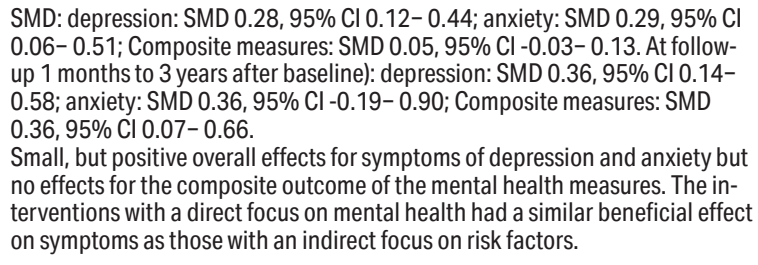 \\
\hline $\begin{array}{l}\text { Montano et } \\
\text { al, } 2014(20)\end{array}$ & $\mathrm{N}=7$ (RCT) & $\begin{array}{l}\text { Cognitive behavioral, ergonomics, health } \\
\text { education, health promotion, physical activity, } \\
\text { stress management. }\end{array}$ & $\begin{array}{l}\text { Standardized mean differences (SMD): job stress: }-0.37,95 \% \mathrm{Cl}-0.71--0.04 \text {. } \\
\text { Workplace interventions can have small, but positive effects on health } \\
\text { outcomes }\end{array}$ \\
\hline
\end{tabular}

a High quality review.

interventions, Carolan et al (17) found a significant positive effect size for psychological wellbeing, including depression, stress and distress. Psychological interventions delivered through the internet, mobile technology, or computer, were found to be effective on mental health among a diverse worker population. The second high quality review also concluded a small and positive effect of workplace interventions aimed at the prevention of depression with more pronounced effects of interventions that used cognitive behavioral therapy techniques than other interventions (22).

There were $2(18,34)$ low quality reviews that evaluated the effect of workplace physical activity interventions on mental health. Chu et al (34) concluded moderate evidence for the effect of physical activity interventions on depressive symptoms. In addition, Conn et al (18) found positive effect sizes, though not statistically significant, indicating better mental health outcomes for those receiving physical activity interventions. The remaining 2 low quality reviews $(19,20)$ included a diverse set of interventions including cognitive behavioral, ergonomics, health education, health promotion, physical activity, and stress management. Both reviews reported overall positive, but small effects on depression and anxiety (19) and job stress (20).

In sum, based on the high quality reviews, there is strong evidence that workplace psychological interventions, especially those that use e-health and cognitive behavior techniques yield positive effects.

\section{Effect of interventions on musculoskeletal disorders}

The evidence with respect to the effectiveness of worksite health promotion interventions on musculoskeletal disorders was summarized in 6 reviews $(20,23,35-38)$, of which 4 were of high quality $(23,35,36,38)$ (table 7). Most reviews used a general musculoskeletal health measure as outcome (eg, musculoskeletal disorders, symptoms, or health), while $2(23,37)$ used a specific musculoskeletal health outcome. Namely, Verbeek et al (23) studied the effect on (incidence, duration, frequency of intensity of) back pain, and Van Eerd et al (37) evaluated the effect of workplace interventions on upper-extremity disorders and symptoms. 
Table 7. Description of the reviews that studied the effect on musculoskeletal health outcomes. [OR=odds ratio; $\mathrm{RR}=$ risk ratio; $\mathrm{Cl}=$ confidence interval.]

\begin{tabular}{|c|c|c|c|}
\hline Review & $\begin{array}{l}\text { Number and type of } \\
\text { studies }\end{array}$ & Type of intervention & Author's conclusion \\
\hline $\begin{array}{l}\text { Krungkraipetch } \\
\text { et al, } 2012 \\
(35)^{a}\end{array}$ & $\begin{array}{l}\mathrm{N}=8 \text { ( } 2 \text { RCT, } 3 \text { quasi exper- } \\
\text { imental studies, } 2 \text { cohort } \\
\text { studies, } 1 \text { case study with } \\
\text { pre-post evaluation) }\end{array}$ & $\begin{array}{l}\text { Interventions targeted biomechanical } \\
\text { exposure in the workplace or the organiza- } \\
\text { tion of work and included health beliefs and } \\
\text { attitudes of workers. Three types of inter- } \\
\text { ventions: (i) mechanical exposure interven- } \\
\text { tions, (ii) production systems/ organiza- } \\
\text { tional culture interventions and (ii) modifier } \\
\text { intervention. }\end{array}$ & $\begin{array}{l}\text { Very limited evidence to support the use of three types of interven- } \\
\text { tions, mechanical exposure, production systems/organizational culture } \\
\text { and modifier interventions for reducing the incidence, prevalence and } \\
\text { intensity of musculoskeletal disorders and to reduce risk factors among } \\
\text { informal sector workers. }\end{array}$ \\
\hline $\begin{array}{l}\text { Tullar et al, } \\
2010(36)^{\text {a }}\end{array}$ & $\begin{array}{l}\mathrm{N}=40 \text { (RCT or non- } \mathrm{RCT} \\
\text { with a control group; } \\
\mathrm{N}=16 \text { were of medium } \\
\text { or high quality and in- } \\
\text { cluded in best evidence } \\
\text { synthesis) }\end{array}$ & $\begin{array}{l}\text { Occupational safety and health interven- } \\
\text { tions in health care settings; primary and } \\
\text { secondary prevention interventions con- } \\
\text { ducted at the workplace. Most interventions } \\
\text { were multi-component interventions ( } 3 \text { of } \\
\text { 16) and exercise interventions ( } 5 \text { of } 16)\end{array}$ & $\begin{array}{l}\text { A moderate level of evidence for a positive effect on improving musculo- } \\
\text { skeletal health was found for multicomponent patient handling interven- } \\
\text { tions and for exercise programs. }\end{array}$ \\
\hline 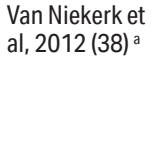 & $\begin{array}{l}\mathrm{N}=5 \text { ( } 3 \mathrm{RCT}, 1 \text { pre-post } \\
\text { study, } 1 \text { single case study) }\end{array}$ & $\begin{array}{l}\text { Chair interventions, chair modifications. } \\
\text { Most common feature was an adjust- } \\
\text { able sea or back height, and the training } \\
\text { in the use of the chair i.e. how to adjust } \\
\text { appropriately. }\end{array}$ & $\begin{array}{l}\text { A consistent trend that supports the role of a chair intervention to reduce } \\
\text { musculoskeletal symptoms among workers who are required to sit for } \\
\text { prolonged periods. However, the amount and level of quality of evidence } \\
\text { was moderate thus not making strong recommendations. }\end{array}$ \\
\hline $\begin{array}{l}\text { Verbeek et al, } \\
2011(23)^{a}\end{array}$ & $\begin{array}{l}\mathrm{N}=18 \text { ( } 9 \text { RCT and } \\
9 \text { cohort studies) }\end{array}$ & $\begin{array}{l}\text { Professional education, video, use of back } \\
\text { belt, exercise, and occupational training } \\
\text { plus lifting aids }\end{array}$ & $\begin{array}{l}\text { Moderate quality evidence from } 7 \mathrm{RCT} \text { that those who received training } \\
\text { reported levels of back pain similar to those with no intervention, with } \\
\text { an OR of } 1.17(95 \% \mathrm{Cl} 0.68-2.02) \text { or minor advice (video) with a RR of } \\
0.93(95 \% \mathrm{Cl} 0.69-1.25) \text {. Results of the cohort studies were similar to } \\
\text { those of the RCT. }\end{array}$ \\
\hline $\begin{array}{l}\text { Montano et al, } \\
2014(20)\end{array}$ & $\mathrm{N}=12(\mathrm{RCT})$ & $\begin{array}{l}\text { Cognitive behavioral, ergonomics, health } \\
\text { education, health promotion, physical ac- } \\
\text { tivity, stress management }\end{array}$ & $\begin{array}{l}\text { Workplace interventions can have small, but positive effects on health } \\
\text { outcomes. Standardized mean difference (SMD) for MSD: }-0.32,95 \% \mathrm{Cl} \\
-0.51--0.14 \text {. }\end{array}$ \\
\hline $\begin{array}{l}\text { Van Eerd et al, } \\
2016(37)\end{array}$ & $\begin{array}{l}\mathrm{N}=61 \text { ( } 26 \text { medium or } \\
\text { high quality } \mathrm{RCT} \text {, } \\
\text { non-RCT with a control } \\
\text { group }+35 \text { from an earlier } \\
\text { review) }\end{array}$ & $\begin{array}{l}30 \text { different workplace interventions for } \\
\text { preventing and managing upper MSD }\end{array}$ & $\begin{array}{l}\text { Implementing a workplace based resistance training exercise program, } \\
\text { policy or practice can help manage and prevent upper MSD. } \\
\text { Strong evidence for } 1 \text { intervention category: resistance exercise train- } \\
\text { ing; moderate evidence for stretching programs, mouse use feedback } \\
\text { and forearm supports. Moderate evidence for no benefit for EMG } \\
\text { biofeedback, job stress management training and office workstation } \\
\text { adjustment. }\end{array}$ \\
\hline
\end{tabular}

a High quality review.

A similar overall conclusion was reached in $3(35$, $36,38)$ of the high quality reviews in that they found limited to moderate evidence for a positive effect of the workplace interventions under review. Based on 16 medium or high quality RCT or non-RCT with a control group, Tullar et al (36) concluded moderate evidence for a broad range of occupational safety and health primary and secondary prevention interventions on musculoskeletal symptoms in healthcare workers. Krungkraipetch et al (35) backed this finding, concluding limited evidence to support the use of three types of interventions to reduce musculoskeletal disorders. The interventions in that review were mostly multi-component or exercise interventions. Furthermore, although all five studies included in the review of Van Niekerk et al (38) found a reduction in self-reported musculoskeletal pain in desk workers, the amount and level of quality of evidence was moderate. The fourth high quality review (23) concluded that training proper manual handling techniques or assistive devices are not effective to prevent back pain in those who have manual handling to the extent that it increases their risk for back pain.
The remaining reviews that were considered of low quality $(20,37)$ had inconsistent results to some extent. While Montano et al (20) showed a positive, but small effect of various workplace interventions on musculoskeletal health, Van Eerd et al (37) found strong evidence for one intervention type on upper-extremity disorders, ie, resistance exercise training. Based on a total of 61 RCT and non-RCT with a control group, Van Eerd et al concluded moderate evidence for stretching programs, mouse use feedback, and forearm supports. In contrast, some other interventions were not supported, with moderate evidence for no benefit of electromyography biofeedback, job stress management training and office workstation adjustments.

To conclude, as $75 \%$ of the high quality reviews found some evidence for positive effects, there is strong evidence for the support of workplace interventions to the prevention of musculoskeletal disorders. An exception was the training of proper manual handling techniques or the use of assistive devices, which seemed not effective in the prevention of back pain. Table 8 summarizes the conclusions with respect to the levels of evidence per outcome measure. 
Table 8. Levels of evidence for workplace health promotion interventions per outcome.

\begin{tabular}{|c|c|c|c|}
\hline Outcome & $\begin{array}{l}\text { Low/high quality } \\
\text { reviews (N) }\end{array}$ & $\begin{array}{l}\text { Level of evidence } \\
\text { meta-review }{ }^{a}\end{array}$ & Comment \\
\hline Weight-related & $11 / 3$ & *** & 3 high quality studies concluded positive, though small effects. \\
\hline Metabolic risk & $5 / 0$ & 0 & 0 high quality reviews, inconsistent conclusions of low quality reviews. \\
\hline Mental health & $4 / 2$ & *** & 2 high quality reviews concluded small positive effects for e-health and interventions using CBT techniques. \\
\hline Musculoskeletal health & $2 / 4$ & *** & $\begin{array}{l}3 \text { high quality reviews concluded positive effects of workplace interventions; } 1 \text { high quality review con- } \\
\text { cluded no effect of training proper manual handling techniques or assistive devices. }\end{array}$ \\
\hline
\end{tabular}

a Levels of evidence were defined as: ${ }^{* *}$ Strong evidence: $>1$ high-quality reviews with consistent outcomes; ** Moderate evidence: 1 high-quality and $\geq 1$ low-quality reviews with consistent outcomes; *Limited evidence: only 1 high-quality, or >1 low-quality reviews, all with consistent outcomes; 0 No evidence: only 1 low-quality review, or inconsistent results of the reviews.

\section{Discussion}

This systematic review aimed to summarize the evidence from reviews on the effectiveness of health promotion interventions at the workplace on various physical and mental health outcomes that are related to (the prevention of) chronic diseases, ie, cardiometabolic risk factors as predictors for T2DM and CVD, mental health, and musculoskeletal disorders. We found strong evidence for positive effects of such workplace initiatives on weight-related outcomes, mental health, and musculoskeletal health. The evidence for an effect of workplace interventions on cardiometabolic risk factors, except for weight-related measures, was inconsistent.

The main strengths of this review are the use of meta-review methodology, which enabled coverage of very broad range of health outcomes, the comprehensive search strategy and the quality assessment of each review by two independent researchers. However, the results should be interpreted in the light of some limitations. For study quality, we calculated an overall AMSTAR score and used an arbitrary cut-off (ie, $50 \%$ ) to distinguish low and high quality reviews. Both approaches are discussed in the literature, since the calculation of an overall quality score assumes that all questions are of equal importance and different cutoffs exist $(39,40)$. Both other cut-off points to define reviews of high quality as well as a three category approach (with low, moderate, and high quality) have been used to distinguish between reviews of higher or lower quality (39). However, meta-reviews that applied a three category approach often merged findings from moderate and high quality studies in the same category for an evidence synthesis (16). Therefore, and following previously published reviews $(14,15)$, we decided to use a dichotomy and a cut-off of $50 \%$. If we would have used a higher cut-off point, for example of $75 \%$, as has been done in other reviews [eg, (41)], there would only be one high quality review (21), logically yielding lower evidence conclusions.

As this review found strong evidence for an effect on weight-related outcomes, but not for other cardio- metabolic risk factors, it is unknown whether workplace health promotion in the long-term may lead to a reduced incidence of CVD and T2DM. Inconsistencies in the results of multiple reviews hamper decision makers or other stakeholders involved in the prevention of chronic diseases to implement evidence-based interventions (42). This meta-review shows that for weight-related outcomes, mental disorders and musculoskeletal problems consistent positive effects were found of workplace health promotion. Most of the original systematic reviews in this meta-review included a range of very different interventions, which is an important limitation of this review. The studies included not only showed a large heterogeneity in the interventions but also in the outcomes under study. For example, for mental health disorders, the outcomes included depressive symptoms, anxiety, psychological wellbeing, mood, and job stress. The various outcomes may imply different intervention strategies to be effective. This may explain the heterogeneity of the interventions, where those targeting mental health included e-health, cognitive behavioral therapy (CBT) techniques, individual and group-based physical activity interventions, stress management and training in coping skills $(17-20,22,34)$. Wherever possible, we indicated the specific interventions for which effectiveness was concluded. For the prevention of mental disorders, these were cognitive behavioral intervention and e-health. Although CBT is particularly applied to patients, these techniques were included in workplace health promotion interventions to target behavioral changes to promote (mental) health (22). CBT intervention has shown to be effective in the prevention and reduction of anxiety problems (25). From this preventive perspective and the focus on behavioral change to promote health, we considered this type of intervention eligible in this review. In general, other reviews on health promotion in the workplace conclude that comprehensive multimodal interventions, including different intervention components, are more effective in the prevention of chronic disease compared to single component interventions (43-45). With respect to a broad implementation of multimodal interventions it is not clear which components in what dose or frequency 
should be applied and recommendations for employers are therefore not easy to formulate. Another important challenge for employers who intend to prevent chronic diseases is the implementation of health promotion interventions. As a precondition for a successful implementation, it is advised to assess the needs and possibilities at different levels $(44,46)$. To take a next step and support employers with a practical toolkit for implementing workplace health promotion to prevent overweight, mental and musculoskeletal disorders, more insight in facilitating factors and barriers for the implementation of worksite health promotion interventions is needed.

\section{Acknowledgement}

The current study was part of joint action CHRODIS PLUS, which has received funding from the European Union, in the framework of the Health Program (20142020), grant agreement number 761307 . The authors would like to thank Jaana Lindstrom of the National Institute for Health and welfare (THL), Finland, and Matilde Leonardi from the Foundation IRCCS Neurological Institute "Carlo Besta" (FINCB), Italy, for their role as project leaders of the joint action CHRODIS PLUS work package.

\section{Conflict of interest}

The author declare no conflict of interest.

\section{References}

1. World Health Organisation (WHO). Preventing chronic diseases: a vital investment. Geneva: WHO; 2005.

2. World Health Organisation (WHO). Preventing Noncommunicable Diseases in the Workplace through Diet and Physical Activity. Geneva: WHO / World Economic Forum 2008.

3. Bevan S, Quadrello T, McGee R. Fit for work? Musculoskeletal disorders in the European workforce. London: The Work Foundation; 2009.

4. Black CM. Sickness absence and musculoskeletal disorders. Rheumatology (Oxford) 2012 Feb;51(2):204-5. https://doi. org/10.1093/rheumatology/ker323.

5. Cattrell A, Harris EC, Palmer KT, Kim M, Aylward M, Coggon D. Regional trends in awards of incapacity benefit by cause. Occup Med (Lond) 2011 May;61(3):148-51. https://doi.org/10.1093/occmed/kqr008.

6. Murray CJ, Vos T, Lozano R, Naghavi M, Flaxman AD, Michaud C et al. Disability-adjusted life years (DALYs) for 291 diseases and injuries in 21 regions, 1990-2010: a systematic analysis for the Global Burden of Disease Study
2010. Lancet 2012 Dec;380(9859):2197-223. https://doi. org/10.1016/S0140-6736(12)61689-4.

7. Goetzel RZ, Pei X, Tabrizi MJ, Henke RM, Kowlessar N, Nelson CF et al. Ten modifiable health risk factors are linked to more than one-fifth of employer-employee health care spending. Health Aff (Millwood) 2012 Nov;31(11):2474-84 https://doi.org/10.1377/hlthaff.2011.0819.

8. Kleinman N, Abouzaid S, Andersen L, Wang Z, Powers A. Cohort analysis assessing medical and nonmedical cost associated with obesity in the workplace. J Occup Environ Med 2014 Feb;56(2):161-70. https://doi.org/10.1097/ JOM.0000000000000099.

9. Feigin VL, Roth GA, Naghavi M, Parmar P, Krishnamurthi $\mathrm{R}$, Chugh $\mathrm{S}$ et al.; Global Burden of Diseases, Injuries and Risk Factors Study 2013 and Stroke Experts Writing Group. Global burden of stroke and risk factors in 188 countries, during 1990-2013: a systematic analysis for the Global Burden of Disease Study 2013. Lancet Neurol 2016 Aug;15(9):913-24. https://doi.org/10.1016/S14744422(16)30073-4.

10. Lim SS, Vos T, Flaxman AD, Danaei G, Shibuya K, Adair-Rohani $\mathrm{H}$ et al. A comparative risk assessment of burden of disease and injury attributable to 67 risk factors and risk factor clusters in 21 regions, 1990-2010: a systematic analysis for the Global Burden of Disease Study 2010. Lancet 2012 Dec;380(9859):2224-60. https://doi. org/10.1016/S0140-6736(12)61766-8.

11. Moher D, Liberati A, Tetzlaff J, Altman DG; PRISMA Group. Preferred reporting items for systematic reviews and meta-analyses: the PRISMA statement. PLoS Med 2009 Jul;6(7):e1000097. https://doi.org/10.1371/journal. pmed.1000097.

12. Shea BJ, Hamel C, Wells GA, Bouter LM, Kristjansson $\mathrm{E}$, Grimshaw $\mathrm{J}$ et al. AMSTAR is a reliable and valid measurement tool to assess the methodological quality of systematic reviews. J Clin Epidemiol 2009 Oct;62(10):101320. https://doi.org/10.1016/j.jclinepi.2008.10.009.

13. Shea BJ, Grimshaw JM, Wells GA, Boers M, Andersson N, Hamel C et al. Development of AMSTAR: a measurement tool to assess the methodological quality of systematic reviews. BMC Med Res Methodol 2007 Feb;7:10. https:// doi.org/10.1186/1471-2288-7-10.

14. Groeneveld IF, Proper KI, van der Beek AJ, Hildebrandt VH, van Mechelen W. Lifestyle-focused interventions at the workplace to reduce the risk of cardiovascular disease-a systematic review. Scand J Work Environ Health 2010 May;36(3):202-15. https://doi.org/10.5271/sjweh.2891.

15. Hayden JA, Côté P, Bombardier C. Evaluation of the quality of prognosis studies in systematic reviews. Ann Intern Med 2006 Mar;144(6):427-37. https://doi.org/10.7326/00034819-144-6-200603210-00010.

16. Joyce S, Modini M, Christensen H, Mykletun A, Bryant $\mathrm{R}$, Mitchell $\mathrm{PB}$ et al. Workplace interventions for common mental disorders: a systematic meta-review. Psychol Med 2016 Mar;46(4):683-97. https://doi.org/10.1017/ S0033291715002408. 
17. Carolan S, Harris PR, Cavanagh K. Improving employee well-being and effectiveness: systematic review and metaanalysis of web-based psychological interventions delivered in the workplace. J Med Internet Res 2017 Jul;19(7):e271. https://doi.org/10.2196/jmir.7583.

18. Conn VS, Hafdahl AR, Cooper PS, Brown LM, Lusk SL. Meta-analysis of workplace physical activity interventions. Am J Prev Med 2009 Oct;37(4):330-9. https://doi. org/10.1016/j.amepre.2009.06.008.

19. Martin A, Sanderson K, Cocker F. Meta-analysis of the effects of health promotion intervention in the workplace on depression and anxiety symptoms. Scand J Work Environ Health 2009 Jan;35(1):7-18. https://doi.org/10.5271/ sjweh.1295.

20. Montano D, Hoven H, Siegrist J. A meta-analysis of health effects of randomized controlled worksite interventions: does social stratification matter? Scand J Work Environ Health 2014 May;40(3):230-4. https://doi.org/10.5271/ sjweh.3412.

21. Power BT, Kiezebrink K, Allan JL, Campbell MK. Effects of workplace-based dietary and/or physical activity interventions for weight management targeting healthcare professionals: a systematic review of randomised controlled trials. BMC Obes. 2014 Nov 14;1:23. doi: 10.1186/s40608014-0023-3.

22. Tan L, Wang MJ, Modini M, Joyce S, Mykletun A, Christensen $\mathrm{H}$ et al. Preventing the development of depression at work: a systematic review and meta-analysis of universal interventions in the workplace. BMC Med 2014 May;12(1):74. https://doi.org/10.1186/1741-7015-12-74.

23. Verbeek JH, Martimo KP, Karppinen J, Kuijer PP, ViikariJuntura E, Takala EP. Manual material handling advice and assistive devices for preventing and treating back pain in workers. Cochrane database of systematic reviews (Online). 2011(6):CD005958.

24. Verweij LM, Coffeng J, van Mechelen W, Proper KI. Meta-analyses of workplace physical activity and dietary behaviour interventions on weight outcomes. Obes Rev 2011 Jun;12(6):406-29. https://doi.org/10.1111/j.1467789X.2010.00765.x.

25. Hafez D, Fedewa A, Moran M, O’Brien M, Ackermann R, Kullgren JT. Workplace Interventions to Prevent Type 2 Diabetes Mellitus: a Narrative Review. Curr Diab Rep 2017 Feb;17(2):9. https://doi.org/10.1007/s11892-017-0840-0.

26. Anger WK, Elliot DL, Bodner T, Olson R, Rohlman DS, Truxillo DM et al. Effectiveness of total worker health interventions. J Occup Health Psychol 2015 Apr;20(2):22647. https://doi.org/10.1037/a0038340.

27. Kwak L, Hagströmer M, Jensen I, Karlsson ML, Alipour A, Elinder LS. Promoting physical activity and healthy dietary behavior: the role of the occupational health services: a scoping review. J Occup Environ Med 2014 Jan;56(1):3546. https://doi.org/10.1097/JOM.0000000000000012.

28. Anderson LM, Quinn TA, Glanz K, Ramirez G, Kahwati LC, Johnson DB et al.; Task Force on Community Preventive
Services. The effectiveness of worksite nutrition and physical activity interventions for controlling employee overweight and obesity: a systematic review. Am J Prev Med 2009 Oct;37(4):340-57. https://doi.org/10.1016/j. amepre.2009.07.003.

29. Archer WR, Batan MC, Buchanan LR, Soler RE, Ramsey DC, Kirchhofer A et al. Promising practices for the prevention and control of obesity in the worksite. Am J Health Promot 2011 Jan-Feb;25(3):e12-26. https://doi. org/10.4278/ajhp.080926-LIT-220.

30. Fernandez ID, Becerra A, Chin NP. Worksite Environmental Interventions for Obesity Prevention and Control: Evidence from Group Randomized Trials. Curr Obes Rep 2014 Jun;3(2):223-34. https://doi.org/10.1007/s13679-014-01004.

31. Mehta S, Dimsdale J, Nagle B, Holub CK, Woods C, Barquera $\mathrm{S}$ et al. Worksite interventions: improving lifestyle habits among Latin American adults. Am J Prev Med 2013 May;44(5):538-42. https://doi.org/10.1016/j. amepre.2013.01.015.

32. Tam G, Yeung MPS. A systematic review of the long-term effectiveness of work-based lifestyle interventions to tackle overweight and obesity. Prev Med. 2018 Feb;107:54-60. https://doi.org/10.1016/j.ypmed.2017.11.011.

33. Vuillemin A, Rostami C, Maes L, Van Cauwenberghe E, Van Lenthe FJ, Brug $J$ et al. Worksite physical activity interventions and obesity: a review of European studies (the HOPE project). Obes Facts 2011;4(6):479-88. https://doi. org/10.1159/000335255.

34. Chu AH, Koh D, Moy FM, Müller-Riemenschneider F. Do workplace physical activity interventions improve mental health outcomes? Occup Med (Lond) 2014 Jun;64(4):23545. https://doi.org/10.1093/occmed/kqu045.

35. Krungkraipetch N, Krungkraipetch K, Kaewboonchoo O, Arphorn S, Sim M. Interventions to prevent musculoskeletal disorders among informal sector workers: a literature review. Southeast Asian J Trop Med Public Health 2012 Mar;43(2):510-25.

36. Tullar JM, Brewer S, Amick BC 3rd, Irvin E, Mahood Q, Pompeii LA et al. Occupational safety and health interventions to reduce musculoskeletal symptoms in the health care sector. J Occup Rehabil 2010 Jun;20(2):199-219. https://doi.org/10.1007/s10926-010-9231-y.

37. Van Eerd D, Munhall C, Irvin E, Rempel D, Brewer S, van der Beek AJ et al. Effectiveness of workplace interventions in the prevention of upper extremity musculoskeletal disorders and symptoms: an update of the evidence. Occup Environ Med 2016 Jan;73(1):62-70. https://doi.org/10.1136/ oemed-2015-102992.

38. van Niekerk SM, Louw QA, Hillier S. The effectiveness of a chair intervention in the workplace to reduce musculoskeletal symptoms. A systematic review. BMC Musculoskelet Disord 2012 Aug;13:145. https://doi. org/10.1186/1471-2474-13-145.

39. Pieper D, Koensgen N, Breuing J, Ge L, Wegewitz U. How 
is AMSTAR applied by authors - a call for better reporting. BMC Med Res Methodol 2018 Jun;18(1):56. https://doi. org/10.1186/s12874-018-0520-z.

40. Pollock M, Fernandes RM, Hartling L. Evaluation of AMSTAR to assess the methodological quality of systematic reviews in overviews of reviews of healthcare interventions. BMC Med Res Methodol 2017 Mar;17(1):48. https://oi.org/10.1186/s12874-017-0325-5.

41. Proper KI, van de Langenberg D, Rodenburg W, Vermeulen $\mathrm{RC}$, van der Beek AJ, van Steeg $\mathrm{H}$ et al. The Relationship Between Shift Work and Metabolic Risk Factors: A Systematic Review of Longitudinal Studies. Am J Prev Med 2016 May;50(5):e147-57. https://doi.org/10.1016/j. amepre.2015.11.013.

42. Jadad AR, Cook DJ, Browman GP. A guide to interpreting discordant systematic reviews. CMAJ 1997 May;156(10):1411-6.

43. Seymour L, Grove B. Workplace interventions for people with common mental health problems. London: British occupational health research foundation; 2005.

44. Goldgruber J, Ahrens D. Effectiveness of workplace health promotion and primary prevention interventions: A review. J Public Health (Bangkok) 2010;18(1):75-88. https://doi. org/10.1007/s10389-009-0282-5.

45. Schröer S, Haupt J, Pieper C. Evidence-based lifestyle interventions in the workplace--an overview. Occup Med (Lond) 2014 Jan;64(1):8-12. https://doi.org/10.1093/ occmed/kqt136.

46. Harvey SB, Joyce S, Tan L, Johnson A, Nguyen H, Modini $\mathrm{M}$ et al. Developing a mentally healthy workplace: a review of the literature. Sydney: National Mental Health Commission and the Mentally Healthy Workplace Alliance; 2014.

47. Gudzune K, Hutfless S, Maruthur N, Wilson R, Segal J. Strategies to prevent weight gain in workplace and college settings: a systematic review. Prev Med 2013 Oct;57(4):26877. https://doi.org/10.1016/j.ypmed.2013.03.004.

48. Wolfenden L, Goldman S, Stacey FG, Grady A, Kingsland $\mathrm{M}$, Williams $\mathrm{CM}$ et al. Strategies to improve the implementation of workplace-based policies or practices targeting tobacco, alcohol, diet, physical activity and obesity. Cochrane Database Syst Rev 2018 Nov;11:CD012439.

49. Neil-Sztramko SE, Pahwa M, Demers PA, Gotay CC.
Health-related interventions among night shift workers: a critical review of the literature. Scand J Work Environ Health 2014 Nov;40(6):543-56. https://doi.org/10.5271/ sjweh.3445.

50. Kennedy CA, Amick BC 3rd, Dennerlein JT, Brewer S, Catli S, Williams R et al. Systematic review of the role of occupational health and safety interventions in the prevention of upper extremity musculoskeletal symptoms, signs, disorders, injuries, claims and lost time. J Occup Rehabil 2010 Jun;20(2):127-62. https://doi.org/10.1007/ s10926-009-9211-2.

51. Lunt JA, Sheffield D, Bell N, Bennett V, Morris LA. Review of preventative behavioural interventions for dermal and respiratory hazards. Occup Med (Lond) 2011 Aug;61(5):311-20. https://doi.org/10.1093/occmed/kqr099.

52. van Holland BJ, Soer R, de Boer MR, Reneman MF, Brouwer S. Preventive occupational health interventions in the meat processing industry in upper-middle and highincome countries: a systematic review on their effectiveness. Int Arch Occup Environ Health 2015 May;88(4):389-402. https://doi.org/10.1007/s00420-014-0964-3.

53. Furlan AD, Gnam WH, Carnide N, Irvin E, Amick BC 3rd, DeRango K et al. Systematic review of intervention practices for depression in the workplace. J Occup Rehabil 2012 Sep;22(3):312-21. https://doi.org/10.1007/s10926011-9340-2.

54. Lee NK, Roche A, Duraisingam V, Fischer JA, Cameron J. Effective interventions for mental health in male-dominated workplaces. Ment Health Rev (Brighton) 2014;19(4):23750. https://doi.org/10.1108/MHRJ-09-2014-0034.

55. Arena R, Guazzi M, Briggs PD, Cahalin LP, Myers J, Kaminsky LA et al. Promoting health and wellness in the workplace: a unique opportunity to establish primary and extended secondary cardiovascular risk reduction programs. Mayo Clin Proc 2013 Jun;88(6):605-17. https:// doi.org/10.1016/j.mayocp.2013.03.002.

56. Cairns JM, Bambra C, Hillier-Brown FC, Moore HJ, Summerbell CD. Weighing up the evidence: a systematic review of the effectiveness of workplace interventions to tackle socio-economic inequalities in obesity. J Public Health (Oxf) 2015 Dec;37(4):659-70.

57. Thorndike AN. Workplace Interventions to Reduce Obesity and Cardiometabolic Risk. Curr Cardiovasc Risk Rep 2011 Feb;5(1):79-85. https://doi.org/10.1007/s12170-010-01380 .

Received for publication: 19 February 2019 